\title{
The Effects of Konjac Flour on the Blood Lipids in the Elderly Subjects
}

Fujio Terasawa, Keisuke Tsuji*, Etsuko Tsuji*, Sumiko Oshima*, Shinjiro Suzuki*, and Masuji Seki**

The Third Department of Internal Medicine, Faculty of Medicine, University of Tokyo,

*The National Institute of Nutrition, **The Yokufūkai Geriatric Hospital

\author{
老年者血中脂質に及ぼすコンニャク精粉の影響 \\ 寺 沢 富士夫, 辻啓 介*, 辻悦 子*, 大 島 寿美子* \\ 鈴 木 慎次郎*, 関增 爾** \\ 東京大学医学部第三内科, *国立栄養研究所, $* *$ 浴風会病院
}

老人ホーム在住で, 日常的生活を送り, 通常の食事を摂取している高齢女子 12 名に, 4 週間にわたりコンニ ヤク精粉を 1 日 $3 \mathrm{~g}$ （毎食後 $1 \mathrm{~g}$ ）宛投与し，血中脂質に及ぼす影響を観察した結果は次のと括りである。

1) 血清コレステロールの平均值は, 投与前 $237 \mathrm{mg} / \mathrm{d} l$, 投与中 $214 \mathrm{mg} / \mathrm{d} l$, 投与後 $219 \mathrm{mg} / \mathrm{d} l$ で, 投与 中の值は投与前の值に比べて有意に低下していた。

2）血清中性脂肪の平均値は, 投与前 $145 \mathrm{mg} / \mathrm{d} l$, 投与中 $119 \mathrm{mg} / \mathrm{d} l$, 投与後 $109 \mathrm{mg} / \mathrm{d} l$ で, 投与中及び 投与後の值は投与前の值に比べてそれぞれ有意に低下していた。

3）血漿遊離脂酸の平均值は, 投与前 $0.64 \mathrm{mEq} / l$, 投与中 $0.64 \mathrm{mEq} / l$, 投与後 $0.56 \mathrm{mEq} / l$ で, 投与中, 投与後に有意の変化を示さなかった。

4）以上の結果から，コンニャク精粉は血中脂質降下剤として臨床的に有用であると考えられた。

5） 12 名の被験者はいずれす便秘を訴えていたが，症例の $2 / 3$ に便秘の改善をみた。

6）試験期間中，特に副作用は認められなかった。

Konjac flour is purified from the tubers of Amorphophallus koniac K. Koch and consisted mainly of glucomannan. Tsuji ${ }^{1)}$ et al. found the first time that Konjac flour inhibited the experimental hypercholesterolemia in rats. Several scrutinized experimental studies ${ }^{2-7}$ ) concerning with the effects of Konjac flour on cholesterol metabolism have been conducted by researchers of Japan. Innami ${ }^{3)}$ et al. found the inhibitory effect of Konjac flour on the experimental hypertriglycemia in rats. However, the study on the effects of Konjac flour in humans was reported only by Kishida ${ }^{8)}$ et al., in which they observed the lowering effect of Konjac flour on the hypercholesterolemia produced by administration of butter in volunteer young subjects.

This pilot study was carried out to know whether Konjac flour lowers serum cholesterol, serum triglyceride and plasma free fatty acids or not in the elderly subjects who are getting an ordinary living.

\section{Material and Methods}

Twelve females over seventy years old, all residents at Yokufūkai Home for the Aged, were the 
subjects of the study. They were selected by the only cause that they had been suffered from constipation, regardless with the concentrations of the blood lipids. The study was conducted with concurrence of the subjects. Among them, 3 subjects of angina pectoris and 6 subjects of hypertension were included. Mean serum cholesterol and triglyceride levels of all 12 subjects showed somewhat higher than those of equal age and sex obtained by the census study ${ }^{9}$. Six, 8 and 5 subjects were found to have the higher values than the means of the census study as to serum cholesterol, serum triglyceride and plasma free fatty acids, respectively (Table 1). The methods of measurement of serum cholesterol, serum triglyceride and plasma free fatty acids were Sobel and Fernandez's method ${ }^{10)}$, a modification of Fletcher's method ${ }^{11)}$ and Itaya and Ui's method ${ }^{12)}$, respectively. The study was carried out from Jan. to Mar., 1973. The dietary schedule and the way of living of the subjects were ordinary in this period. The energy and nutrients partition per day during this period were as follows; total

Table 1 Subjects

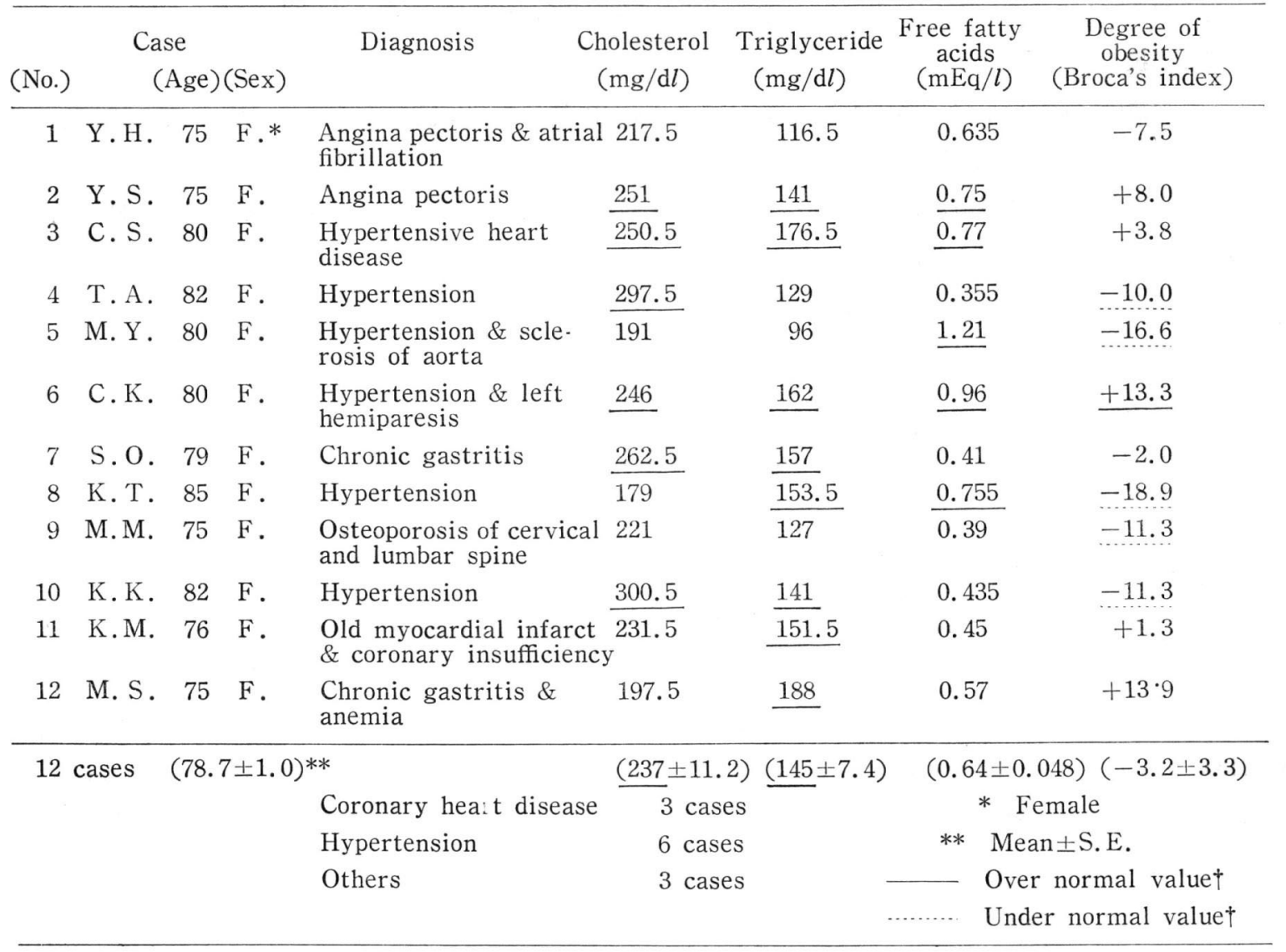

$\dagger$ Ref. for normal values

Cholesterol : Sobel. C. \& Fernandez, A. : Clin. Chem., 12, 739, 1966.

Triglyceride : (Kit of Wakō), Fletcher, M. J. : Clin. Chim. Acta, 22, 393, 1968.

Free fatty acids : (Kit of Wakō), Itaya, K. \& Ui, M., J. Lip. Res., 6, 16, 1965.

Oshima, K. et al. : Arteriosclerosis, 1, 101, 1973.

Fukui, I. et al. : Jap. J. Geriat., 8, 250, 1971.

Isobe, I. : Gifu Med. J., 19, 657, 1971. 
energy; $1,528 \mathrm{kcal}$., protein; $50 \mathrm{~g}$, fat; $24 \mathrm{~g}$ and carbohydrate; $278 \mathrm{~g}$. These values were quite similar to the values of the national nutritional census in 1970. The subjects refrained from taking extra eggs, butter, vegetable oils, dried mashrooms and the like which were considered to influence strongly on the levels of blood lipids. As an example of a daily dietary schedule, one day's food stuffs taken by the subjects and energy and nutrients measurements are shown (Table 2). The blood samples

Table 2 An example of one day's food stuffs taken by the subjects and energy and nutrients measurements (21th, Jan. 1973)

\begin{tabular}{lccccc}
\hline $\begin{array}{l}\text { Commodity of food } \\
\text { stuffs }\end{array}$ & $\begin{array}{c}\text { Weight } \\
\text { (wet weight) }\end{array}$ & $\begin{array}{c}\text { Energy } \\
\text { (kcal) }\end{array}$ & $\begin{array}{c}\text { Protein } \\
(\mathrm{g})\end{array}$ & $\begin{array}{c}\text { Fat } \\
(\mathrm{g})\end{array}$ & $\begin{array}{c}\text { Carbohydrate } \\
\text { (g) }\end{array}$ \\
\hline Highly milled rice & 150 & 527 & 9.3 & 1.2 & 114.9 \\
Bread & 80 & 216 & 6.4 & 1.2 & 43.5 \\
“Miso" (for soup) & 10 & 16 & 1.3 & 0.4 & 1.9 \\
Soybean curd & 50 & 29 & 3.0 & 1.8 & 1.0 \\
Pollack rae & 25 & 29 & 6.5 & 0.3 & 0.3 \\
“Takuwan-zuke" & 20 & 7 & 0.3 & 0.1 & 1.1 \\
Beans sprouts & 50 & 9 & 0 & 1.5 & 0 \\
Carrot, fresh & 20 & 10 & 0.2 & 0.1 & 2.2 \\
Cucumber & 50 & 20 & 0.4 & 0.1 & 0.7 \\
Apple & 150 & 68 & 0.6 & 0.8 & 15.6 \\
Yam & 50 & 61 & 1.8 & 0.1 & 13.3 \\
Great edible burdock & 50 & 38 & 2.1 & 0.1 & 7.4 \\
Dried laver & 5 & 0 & 1.8 & 0.1 & 2.0 \\
Hen's egg & 50 & 78 & 6.4 & 5.6 & 0 \\
Market milk & 180 & 106 & 5.9 & 5.9 & 8.1 \\
Vegetable oil & 10 & 88 & 0 & 10.0 & 0 \\
“Kuri-Manju” & 100 & 300 & 4.6 & 0.2 & 70.2 \\
\hline \multicolumn{1}{c}{ Total } & & 1,602 & 50.6 & 29.5 & 282.2 \\
\hline
\end{tabular}

were taken at 7.00 A. M.. The blood lipids were measured for 2 weeks and just before the beginning of Konjac flour administration, 2 weeks and 4 weeks after the beginning of Konjac fiour administration and 2 weeks after the cessation of Konjac flour administration, respectively. The administered Konjac flour (Shimizu Kagaku Co.) was composed of polysaccharides $82.4 \%$, protein $-\mathrm{N} 0.4 \%$, ashes $1.5 \%$ and of water $14.1 \%$. If water content is substracted, the content of polysaccharides in this Konjac flour becomes 95.9\%. This Konjac flour was administered $3 \mathrm{~g}$ per day, $1 \mathrm{~g}$ after each meal three times during the administration period of 4 weeks. The mean body weight of 12 subjects was $45.7 \mathrm{~kg} \pm 4.5$ (S.E.) in the begining of experiment and $45.5 \mathrm{~kg} \pm 4.3$ (S.E.) in the end.

\section{Results}

Mean values of serum cholestrol and triglyceride, and plasma free fatty acids of 12 sucjects are shown as actual values and as per cent, the standard of the later being the mean values just before the beginning of administration of Konjac flour (Table 3). The mean values of serum cholesterol 
Table 3 The effect of Konjac flour on serum cholesterol, triglyceride and plasma free fatty acids in 12 elderly female subjects

\begin{tabular}{|c|c|c|c|c|c|c|c|}
\hline \multirow[t]{2}{*}{ Weeks } & \multirow[t]{2}{*}{$\mathrm{KF}^{*}$} & \multicolumn{2}{|c|}{ Cholesterol } & \multicolumn{2}{|c|}{ Triglyceride } & \multicolumn{2}{|c|}{ Free fatty acids } \\
\hline & & $(\mathrm{mg} / \mathrm{d} l)$ & $(\%)$ & $(\mathrm{mg} / \mathrm{d} l)$ & $(\%)$ & $(\mathrm{mEq} / l)$ & $(\%)$ \\
\hline-2 & - & $246 \pm 17.0^{* *}$ & $108 \pm 5.5^{* * *}$ & $140 \pm 15.1$ & $97 \pm 5.1$ & $0.50 \pm 0.085$ & $76 \pm 12.1$ \\
\hline 0 & - & $228 \pm 8.8$ & 100 & $148 \pm 8.6$ & 100 & $0.74 \pm 0.091$ & 100 \\
\hline 2 & + & $218 \pm 9.9$ & $96 \pm 4.4$ & $130 \pm 6.5$ & $87 \pm 3.9$ & $0.67 \pm 0.086$ & $92 \pm 4.3$ \\
\hline 4 & + & $211 \pm 10.5$ & $94 \pm 7.7$ & $108 \pm 9.0$ & $76 \pm 4.8$ & $0.63 \pm 0.077$ & $88 \pm 6.0$ \\
\hline-2 & - & $219 \pm 10.3$ & $96 \pm 3.4$ & $109 \pm 8.6$ & $73 \pm 2.9$ & $0.56 \pm 0.071$ & $83 \pm 11.5$ \\
\hline
\end{tabular}

*KF; Konjac flour, **Mean with standard error, ***Rate of change in $\%$ Konjac flour was administered $3 \mathrm{~g} /$ day divided into 3 after each meal.

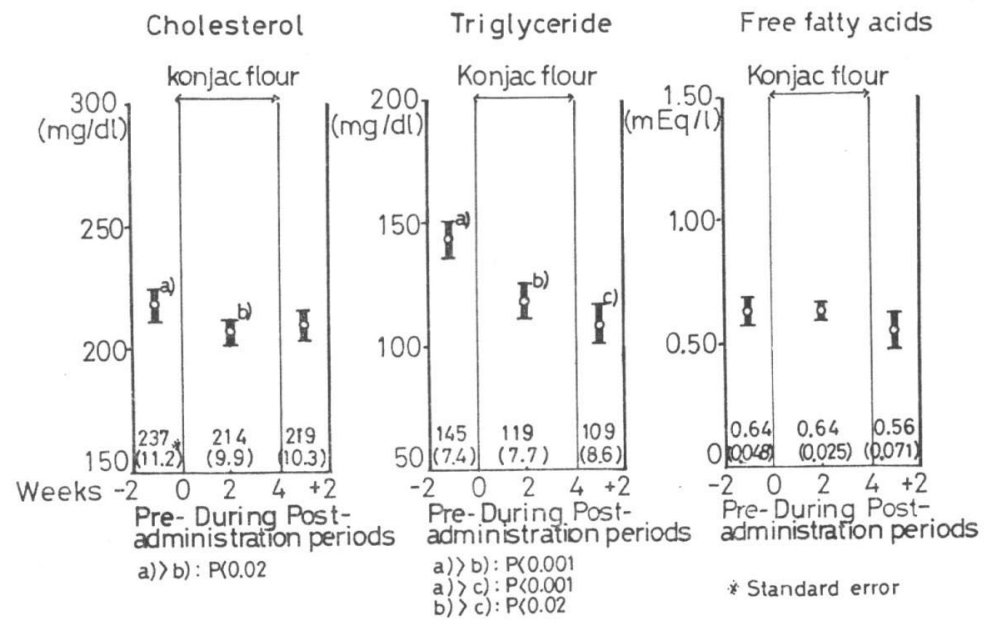

Fig. 1 Effect of "Konjac flour" on Serum Cholesterol, Triglyceride and Plasma Free Fatty Acids in Elderly Subjects

showed the following values; 96\% 2 weeks, $94 \% 4$ weeks after the beginning of administration, respectively, and 96\% 2 weeks after the cessation of administration of Konjac flour. The mean values of serum triglyceride showed the following values; $87 \% 2$ weeks, $76 \% \quad 4$ weeks after the beginning of administration, respectively, and $73 \% 2$ weeks after the cessation of administration of Konjac flour. The mean values of plasma free fatty acids showed the following values; $92 \% 2$ weeks, $88 \% 4$ weeks after the beginning of administration, respectively, and $83 \% 2$ weeks after the cessation of administration of Konjac flour. The modified time course changes of the mean values of three components of blood lipids are shown (Fig. 1). The mean values of serum cholesterol were $237 \mathrm{mg} / \mathrm{d} l$ in preadministration period (the mean of the values of 2 weeks before and of just before and of just before administration on Konjac flour), $214 \mathrm{mg} / \mathrm{d} l$ during administration period (the mean of the values of 2 weeks and of 4 weeks after the beginning of administration of Konjac flour) and $219 \mathrm{mg} / \mathrm{d} l$ in postadministration period (the value 2 weeks after the cessation of administration of Konjac flour). The difference between the mean values in preadministration period and during administration period was statistically significant $(\mathrm{P}<0.02)$. The mean values of serum trigly- 
ceride were $145 \mathrm{mg} / \mathrm{d} l$ in preadministration period, $119 \mathrm{mg} / \mathrm{d} l$ during administration period and 109 $\mathrm{mg} / \mathrm{d} l$ in postadministration period, respectively. The significant difference existed between the mean values in preadministration period and during administration period, and, also, in postadministration period $(\mathrm{P}<0.001 . \mathrm{P}<0.001$, respectively). Morover, significant difference was noted between the mean values during administration period and in postadministration period $(\mathrm{P}<0.02)$. The mean values of plasma free fatty acids were $0.64 \mathrm{mEq} / l$ in preadministration period, $0.64 \mathrm{mEq} / l$ during administration period and $0.56 \mathrm{mEq} / l$ in postadministration period, respectively. No significant differences were noted among these three values.

Comparison among the rates of changes of three blood lipid components revealed that the rate of change in triglyceride was most evident both 2 and 4 weeks after the beginning of administration of Konjac flour. It was not shown that the rate of reduction of each component of blood lipids was greater when the level of each component in preadministration period was higher.

In addendum, the anticonstipational effect was noted in about two-thirds of the subjects. Moreover, adverse reactions, such as allergic one to Konjac flour, gastrointestinal disturbances were not observed in any of the subjects.

\section{Discussion}

In Japan, "Konnyaku" has been one of the vegetables used as daily food and has been manufactured by alkaline coagulation of Konjac mannan contained in tubers of Amorphophallus konjac K. Koch. This "Konnyaku” has been currently used as an weight control agent among peoples, because "Konnyaku" has no speical energy. However, "Konnyaku" has been shown to have no antilipaemic effect. It is due to that in "Konnyaku", Konjac mannan, the main component of Konjac flour, exists in the form of gel-formation ${ }^{4}$.

The suggestion that the effective component of Konjac flour which depresses the blood lipids is glucomannan was made from the fact when Konjac flour was hydrolized by acids or splitted by enzymes, the depressing effect of blood lipids was inactivated ${ }^{12)}$. The chemical structure of Konjac glucomannan has been recently clarified ${ }^{13)}{ }^{14}$. When Konjac Mannan was decomposited, oligosaccharides, composed of monosaccharide to heptasaccharides, were generated and mannose-glucose ratio of these oligosacchrides was about 1.6 to $1^{15)}$. The molecular weight of glucomannan is said to be between $190 \times 10^{4}$ to $67.6 \times 10^{4}$, being different according to races of $A$. konjac.

The mechanism of the depression of serum cholesterol and serum triglyceride by Konjac flour has not been completely clarified as yet now. Inhibition of absorption of cholesterol of dietary origin or of hepatointestinal circulation in intestine is strongly considered. In this respect, Innami ${ }^{3)}$ et al. recognized the increased excretion of fat in feces of the experimental hypertriglycemic rats when Konjac flour was administered. The important factors which elicit the depression of serum cholestrol are said to be the molecular weight and the width of molecule; the molecular weight over $80-90 \times 10^{4}$ and the width of the molecule over $1000 \AA$ are necessary ${ }^{16)}$. Tsuji ${ }^{5)}$ 
et al. revealed that regardiess of the enhancement of cholesterol synthesis in liver, the cholesterol concentration in the serum and liver was unchanged when Konjac flour was administered with the low cholesterol diet in rats. These phenomena were considered as compensatory ones following the inhibition of reabsorption of hepatointestinally circulating neutral sterols or bile acids.

The present study revealed that the administration of Konjac flour to the elderly subjects who had a normal diet caused a significant decrease both in serum cholesterol and triglyceride. In spite of the dfferent dietary condition, this result did not differ from the report by Kishidas) et al., in which Konjac flour was administered to the hypercholesterolemic young subjects fed on fair amount of butter. Innami et al. observed the hypotriglycemic effect of Konjac flour in rats fed the low and high levels of dietary fat ${ }^{3)}$.

\section{Summary}

Konjac flour was administered to 12 elderly female subjects for 4 weeks, whose diet and life style were normal. The effects of Konjac flour on blood lipids were investigated. The administration of Konjac flour caused (1) a significant decrease in serum cholesterol level during the period of administration, (2) a significant reduction in serum triglyceride level during and after the administration, (3) no change in plasma free fatty acid level and, (4) an anticonstipational effect in two-third the subject.

\section{References}

1) Tsuji, K., Oshima, S., Matsuzaki, E., Nakamura, A., Innami, S., Tezuka, T. and Suzuki, S. : Jap. J. Nutr., 26, 113 (1968)

2) Kiriyama, S., Morisaki, H. and Yoshida, A. : J. Nutr., 102, 1689 (1972)

3) Innami, S., Tsuda, A., Otani, Y., Tezuka, T. and Nagayama, A. : Jap. J. Nutr., 31, 91 (1973)

4) Tsuji, K., Oshima, S., Tsuji, E., Suzuki, S., Innami, S., Nakamura, A., Hirayama, T. and Tezuka, T. : Jap. J. Nutr., 31, 151 (1973)

5) Tsuji, K., Horie, Y., Tsuji, E. and Suzuki. S. : Eiyo to Shokuryo, 27, 405 (1974)

6) Tsuji, E., Tsuji, K. and Suzuki, S. : Jap. J. Nutr., 33, 9 (1974)

7) Tsuji, K., Tsuji, E., Suzuki, S., Umemoto, H. and Irie, T. : Jap. J. Nutr., 33, 51 (1975)

8) Kishida, N. and Okimasu, S. : Eiyo to Shokuryo, 23, 135 (1970)

9) Oshima, K. et al. : Domyakukoka, 1, 101 (1973)

10) Sobel, C. and Fernandez, A. : Clin. Chem., 12, 739 (1966)

11) Fletcher, M. J. : Clin. Chim. Acta, 22, 393 (1968)

12) Itaya, K. and Ui, M. : J. Lipid Res., 6, 16 (1965)

13) Sugiyama, N., Shimahara, H. and Andoh, T. : Bull. Chem. Soc. Jap., 45, 561 (1972)

14) Shimahara. H., Suzuki, H., Sugiyama, N. and Nishizawa, K. : Agr. Biol. Chem., 39, 301 (1975)

15) Sugiyama, N., Shimahara, H., Andoh, T. and Takemoto, M. : Agr. Biol. Chem., 37, 9 (1973)

16) Kiriyama, S., Enishi, A, Yoshida, A., Sugiyama, N. and Shimahara, H. : Nutr. Rept. Int., 6, 231 (1972) 